\title{
AGRO-ENTERPRISES AND THEIR ENTREPRENEURIAL CONNECTION
}

\author{
Tošo Kostadinov \\ Institute of Animal Science, Ss. Cyril and Methodius University in Skopje, \\ Blvd. Ilinden 92a, 1000 Skopje, Republic of North Macedonia \\ tosokostadinov@gmail.com
}

\begin{abstract}
A b s t r a c t: Entrepreneurial networking is an effective means of achieving a number of development opportunities for the companies and they can be motivated by market penetration, networking for market development, to facilitate procurement, research and development, distribution, international trade and export and the like. This research indicates the need for entrepreneurial activities depending on the present conditions of small and medium enterprises (SME) from the agro-complex that are the subject of the presentation of this paper. A survey was conducted after which a processing was performed and the data were analyzed and compared with a survey from 2007. The obtained results indicate that agro-enterprises operate mostly with a small number of companies on a contract basis, but there has been visible progress in recent years towards networking of cooperating companies, which increases their competitiveness in the market.
\end{abstract}

Key words: agribusiness; competitiveness; connectivity; cooperation; trust

\section{АГРОПРЕТПРИЈАТИЈА И НИВНО ПРЕТПРИЕМНИЧКО ПОВРЗУВАњЕ}

А п с т р а к т: Претприемничкото поврзување е ефикасно средство за постигнување бројни развојни можности за претпријатиата кои можат да бидат мотивирани со продирање на пазари, вмрежување заради развој на пазар, олеснување на набавките, истражување и развој, дистрибуција, меѓународна трговија и извоз и слично. Ова истражување укажува на потребата од претприемничките активности во зависност од присутните состојби на мали и средни претпријатија (SME) од агрокомплексот, коишто се предмет на презентација на овој труд. Спроведено е анкетно истражување и е извршена обработка на податоците. Тие се анализирани и споредени со истражувањето од 2007 година. Добиените резултати укажуваат на тоа дека агропретпријатијата работат претежно со мал број други претпријатија врз база на договори, но видлив е напредок во последниве години кон вмрежување на претпријатија што соработуваат, што ја зголемува нивната конкурентска способност на пазарот.

Клучни зборови: агропретпријатија; конкурентска способност; поврзување; соработка; доверба

\section{INTRODUCTION}

There are numerous reasons why companies combine power in entrepreneurial connectivity. Their main goal is to achieve economies of scale, increase competitiveness in the domestic and international market, encourage the opportunity to innovate and commercialize new products and services, increase the speed of innovation, enter new markets, increase exports, establish new start-up capital or cost reduction. The connection of companies enables reduction of uncertainty and risk, utilization of geographical differences and complementary professional knowledge, as well as more efficient coordination and ability to meet the needs of large customers, i.e. simpler structure of suppliers.

It has been established that the horizontal and vertical connection of enterprises enables better mutual coordination and helps reduce uncertainty, as it reduces transaction costs. The connection of enterprises at various levels affects the efficiency of enterprises, joint venture decisions, as well as the exchange of information between enterprises.

For small businesses that do not want to grow, or grow slowly due to various circumstances, connecting with other companies provides some featu- 
res and advantages that, in fact, are characteristic of large companies. For small businesses that want to thrive and grow rapidly, connectivity allows them to bridge the lack of resources and potential. Of course, the achievement of benefits must always develop in both directions. Both partner companies should be able to overcome their shortcomings in the alliance. Simply put, the reasons for the connection could be defined as a desire for (Nonaka, I, Takeuchi, H., 1995):

- achieving economies of scale and economics of related products,

- achieving the knowledge economy,

- overcoming transaction costs and offsetting vertical integration,

- internationalization.

Companies that want to achieve economies of scale, economics of related products, and economics of knowledge, artificially expand their horizontal boundaries and connect horizontally. Companies that want to reduce transaction costs and replace vertical integration would expand their vertical boundaries and connect vertically, while companies that want to expand across their borders (internationalize) would connect horizontally and vertically.

Rigsbee identified seven areas in which businesses expect to benefit from connectivity: products, access, operations, technology, growth, organization and finance. The benefits of economies of scale, for example, include (Burns, P. 2001):

- reduction of average costs (production, storage, inventory, procurement, sales, distribution, etc.) due to the increased volume of production,

- more favorable procurement and financial conditions,

- better negotiating position when negotiating with suppliers,

- greater capacity and more efficient use of resources, number,

- reducing the risk with the strength of the

- better access to critical resources,

- ability to deal with significant market changes,

- financial strength and stability,

- greater flexibility and mobility.

Complementary entrepreneurial activities enable the company to achieve cost reduction through specialization. The company does what it does best, leaving the rest to the other member of the association. Smaller enterprises, which are open to innovation and new product development, are often unable to provide resources for this. In order to increase their competitiveness and survival, they need to establish partnerships with other small or large enterprises that have the necessary resources and specific expertise. Among the ways in which companies complement each other are (Burch, J, 1986):

- interdependent products or services,

- complementary technological expertise, complementary professional knowledge of employees and management.

The knowledge-based economy can most obviously be achieved by reducing production costs, with the help of (Budgrav, D. W., Zacharikis, 2006):

- better coordination of entrepreneurial activities,

- shortening the time from product development to its presence on the market,

- less uncertainty,

- less opportunism.

Improved vertical chain coordination is evident in the following examples: lower inventory costs due to prompt procurement, faster conflict resolution in the supply chain and faster response to complaints, greater consistency between raw materials, semi-finished products and final product-toproduct with end-user products and complaints, improved vertical chain productivity, confidence in a common business strategy, etc. Entrepreneurial networking is an effective means of achieving a number of development opportunities for the company:

Connection for market penetration. With this strategy, companies are trying to strengthen and improve existing activities. Connectivity helps participants reduce transaction costs by streamlining and coordinating, leveraging economies of scale, and multiple market share enhancements through vertical collaboration.

Connecting for market development. Cooperation in the field of market development occurs more often when companies with complementary professional knowledge or products are identified with each other. Connection is a means of conquering new markets through existing distribution channels, and exchanging resources.

Diversification connection. The strategy of cooperation to conquer new markets with new products is closely related to the connection. Connecting the company is sometimes a condition for performing certain activities. Often, companies have to look for a local partner in the foreign market to meet 
certain government trade regulations, or form a consortium (multinational) to be able to bid on public sector tenders.

\section{MATERIAL AND METHODS}

The purpose of this research is based on literature, documents and especially on the analysis of the Questionnaire on a random sample of 64 agro-entrepreneurs from the Republic of North Macedonia. The research uses several methods used in social and economic analysis such as: generalization and specialization, induction and deduction, statistical and comparative method.

\section{RESULTS AND DISCUSSION}

Kostadinov and Pendev, in their research from 2007 , on the claims made in the survey questionnaire related to determining the degree of networking of the agro-enterprise, the respondents stated as follows:

- The company with contracts is related to one or more other companies. $2.0 \%$ of the total number of respondents do not agree at all with this statement, and $4.0 \%$ partially disagree, neither yes nor no answered $4.0 \%, 26.0 \%$ partially agree, and $64.0 \%$. completely agree.

- The company cooperates informally in business with one or more other companies. $4.0 \%$ of the respondents do not agree with this statement at all, $38.0 \%$ partially agree, and $58.0 \%$ of the respondents completely agree.

- The company is involved with a business network of companies, which cooperate with each other in the area such as procurement, sales, distribution, research, etc. $84.0 \%$ of the respondents do not agree with this statement at all, $6.0 \%$ partially disagree, neither yes nor no answered $4.0 \%$ and $6.0 \%$ of the respondents completely agree.

- The company operates completely alone and is not essentially related to other companies. $2.0 \%$ of the respondents do not agree with this statement at all, $2.0 \%$ partially disagree, neither yes nor no $2.0 \%, 8.0 \%$ partially agree, and $86.0 \%$ completely agree.

In our research in 2019, on the claims made in the survey questionnaire that refer to determining the degree of networking of the company, the respondents stated as follows:
- The company with contracts is related to one or more other companies. $2.0 \%$ of the total number of respondents do not agree at all with this statement, and $4.0 \%$ partially disagree, neither yes nor no answered $4.0 \%, 16.0 \%$ partially agree, and 74 completely agree.

- The company cooperates informally with one or more other companies. $1.0 \%$ of the respondents do not agree with this statement at all, 23.0\% partially agree, and $76.0 \%$ of the respondents completely agree.

- The company is involved with a business network of companies, which cooperate with each other in the area such as procurement, sales, distribution, research, etc. $72.0 \%$ of the respondents do not agree with this statement at all, $6.0 \%$ partially disagree, neither yes nor no answered $4.0 \%$ and $18.0 \%$ of the respondents completely agree.

- The company operates completely alone and is not essentially related to other companies. $12.0 \%$ of the respondents do not agree with this statement at all, $12.0 \%$ partially disagree, neither yes nor no $2.0 \%, 8.0 \%$ partially agree, and $66.0 \%$ completely agree

\section{CONCLUSION AND RECOMMENDATIONS}

The networking of the enterprise with other business entities from the agro-sector and with other types of formal and informal entities and networks is one of the key factors for successful growth and development of the enterprise itself. Research has shown that companies in the agricultural sector are generally reluctant to network and cooperate with a large number of partners, but there are evident shifts in improving the situation. . Cooperation between enterprises develops trust, reciprocity and similar soft factors that affect the growth and development of the enterprise. The surveyed agribusiness companies mainly work with one or several companies on the basis of agreements, they are not included in the networks of companies that cooperate with each other, and the mentality of the entrepreneur-owners is that they work completely alone and do not connect essentially with others. enterprises. This situation is not only a fruitful field for developing trust for long-term cooperation between companies, but also reduces the efficiency and effectiveness of the development of existing clusters in the agricultural sector and prevents the formation and development of new clusters in the agricultural sector. This all leads to less competitiveness of companies internationally and/or globally. 
As a conclusion and recommendation regarding this perception, we should recommend more intensive and long-term support of the government and social partners for connecting companies in networks, participation in international agribusiness fairs, assistance in organizing various types of presentations and events for opportunities and products from the agricultural sector. and related to innovatively designed offers and activities of various kinds. For example, an agro-tourism cluster may be formed. The support measures, above all, should be aimed at strengthening the competitiveness of agribusinesses, and not towards outdated types of protection of agribusinesses in the Republic of North Macedonia.

\section{REFERENCES:}

Burns, P.: Enterprise and Small Business, Palgrave, Macmillan, London, 2001.

Burch, J.: Entrepreneurship, New York, 1986.

Bydgrave, D, W.,, Zacharakis, A,: The portable MBA in Entrepreneurship, Fourth edition, John Wiley \& Son. Inc. Hoboken, New York, 2006.

Kostadinov, T., Pendev, D.: Small and medium enterprises in the agrocomplex from the vievpoint of the internacionalization, III Symposium Livestock. Production with International Participation, Ohrid 2007.

Nonaka, I., Takeuchi, H,: The Knowledge - Creating Company, New York,Oxford University Press, 1995. 